\title{
POSTPERICARDIOTOMY SYNDROME INCIDENCE, DIAGNOSTIC AND TREATMENT STRATEGIES: EXPERIENCE AT TWO COLLABORATIVE CENTERS
}

\author{
Krešimir Gabaldo ${ }^{1}$, Željko Sutlić ${ }^{2}$, Domagoj Mišković ${ }^{1}$, Marijana Knežević Praveček ${ }^{1,3}$, \\ Đeiti Prvulović ${ }^{1,3}$, Božo Vujeva ${ }^{1}$, Katica Cvitkušić Lukenda ${ }^{1,3}$ and Irzal Hadžibegović ${ }^{4,5}$ \\ ${ }^{1}$ Cardiology Department, Dr. Josip Benčević General Hospital, Slavonski Brod, Croatia; \\ ${ }^{2}$ Department of Cardiac Surgery, Dubrava University Hospital, Zagreb, Croatia; \\ ${ }^{3}$ Faculty of Medicine, Josip Juraj Strossmayer University of Osijek, Osijek, Croatia; \\ ${ }^{4}$ Department of Cardiology, Dubrava University Hospital, Zagreb, Croatia; \\ ${ }^{5}$ Faculty of Dental Medicine and Health, Josip Juraj Strossmayer University of Osijek, Osijek, Croatia
}

SUMMARY - Postpericardiotomy syndrome (PPS) is worsening or new formation of pericardial and/or pleural effusion mostly 1 to 6 weeks after cardiac surgery, as a result of autoimmune inflammatory reaction within pleural and pericardial space. Its incidence varies among different studies and registries (2\% to $30 \%)$, as well as according to the type of cardiac surgery performed. We conducted this retrospective analysis of PPS incidence and diagnostic and treatment strategies in patients referred for cardiac surgery for revascularization, valvular and/or aortic surgery. We retrospectively analyzed 461 patients referred for an urgent or elective cardiac surgery procedure between 2009 and 2015. PPS diagnosis was established using well defined clinical criteria. Demographic and clinical characteristics were used in regression subanalysis among patients having undergone surgery of aortic valve and/or ascending aorta. Within 6 weeks after cardiac surgery, 47 (10.2\%) patients had PPS. The median time from the procedure to PPS diagnosis was 14 days. The incidence of PPS was $26 \%$ after aortic valve and/or aorta surgery, and $7.9 \%$ and $8.3 \%$ after coronary bypass and mitral valve surgery, respectively. Among patients subjected to aortic valve and/or aortic surgery, regression analysis showed significant association of fever, C-reactive protein (CRP) elevation between 5 and $100 \mathrm{mg} / \mathrm{L}$, urgent procedure and postoperative antibiotic use with PPS diagnosis, whereas younger age showed nearsignificant association. All patients had complete resolution of PPS, mostly after corticosteroid therapy, with only 2 cases of recurrent PPS that successfully resolved after colchicine therapy. Pleural drainage was indicated in $15(32 \%)$ patients, whereas only one patient required pericardial drainage. In conclusion, PPS incidence in our retrospective analysis was similar to previous reports. Patients having undergone aortic valve and/or aortic surgery were most likely to develop PPS. The most relevant clinical criteria for diagnosis in these patients were fever, CRP elevation between 5 and $100 \mathrm{mg} / \mathrm{L}$, and pericardial and/or pleural effusion formation or worsening 2 weeks after cardiac surgery.

Key words: Cardiac surgical procedures; Postoperative complications; Pericardial effusion; Pleural effusion; Postpericardiotomy syndrome

\section{Introduction}

Postpericardiotomy syndrome (PPS) is a clinical syndrome consisting of worsening or new formation of pericardial and/or pleural effusion, pericardial rub, chest pain with or without dyspnea, fever, and elevated inflammatory markers. It occurs mostly 1 to 6 weeks
Correspondence to: Asst. Prof. Irzal Hadžibegović, MD, PhD, Department of Cardiology, Dubrava University Hospital, Av. Gojka Suška 6, HR-10000 Zagreb, Croatia

E-mail: irzalh@gmail.com

Received May 3, 2017, accepted January 4, 2018 
after cardiac surgery as a result of inflammatory reaction after surgical cutdown of pericardial space. Pathophysiology research demonstrated antibodies in patients with PPS, thus explaining the syndrome with autoimmune response. Surgical aperture of pericardial space causes tissue damage, bleeding and formation of a certain amount of new fluid that normally resolves within 4 weeks. In PPS, tissue damage triggers autoimmune reaction of the pericardium and pleura that occurs mostly between 1 and 6 weeks after the procedure.

Postpericardiotomy syndrome is considered as one of the most common complications of cardiac surgery in the late postoperative period. Its incidence is close to $10 \%$ but varies among different studies and registries (2\% to $30 \%)$, as well as according to the type of cardiac surgery performed ${ }^{1}$.

The incidence, diagnostic procedures and treatment strategies have been well defined to date ${ }^{1,2}$, with most interesting studies on the prevention of PPS using anti-inflammatory medication in perioperative period for the prevention of $\mathrm{PPS}^{3}$. Early diagnosis is essential in the prevention of potential serious complications. Although most patients have an uncomplicated clinical course with good prognosis after administration of nonsteroidal anti-inflammatory drugs (NSAIDs), corticosteroids or colchicine, some studies report cases of patients with late diagnosis that required pericardial drainage or even redo surgery ${ }^{4}$.

We conducted this retrospective analysis of PPS incidence, risk factors, treatment strategies and treatment response in patients referred for cardiac surgery for revascularization, valvular and/or aortic surgery.

\section{Patients and Methods}

\section{Patients}

We retrospectively analyzed hospital records of 461 patients referred for cardiac surgery from Dr. Josip Benčević General Hospital, Slavonski Brod, Croatia to Dubrava University Hospital, Zagreb, Croatia, between March 2009 and October 2015. The median age of all patients was 69 years, with $64 \%$ of male patients. Isolated coronary artery bypass graft $(\mathrm{CABG})$ surgery was performed in 379 (82\%) patients, whereas 58 (13\%) patients underwent aortic valve or aorta surgery with or without CABG and $24(5 \%)$ patients had mi- tral valve surgery with or without CABG. Diabetes mellitus was present in $24 \%$ of patients, whereas $17 \%$ and $5 \%$ of patients had chronic renal insufficiency and chronic obstructive pulmonary disease (COPD), respectively.

\section{PPS diagnosis}

Identical diagnostic algorithm was set for all patients throughout the observed period, and was based on a clinical diagnosis of moderate or severe PPS requiring medical attention. PPS diagnosis was established in patients with new or worsened pericardial effusion greater than $5 \mathrm{~mm}$ on echocardiography and/ or new or worsened pleural effusion confirmed by chest $\mathrm{x}$-ray within 6 weeks after pericardiotomy cardiac surgery procedure that had at least one of the following additional clinical signs: fever with no obvious infection, elevation of $\mathrm{C}$-reactive protein $(\mathrm{CRP})$ with no obvious infection, pleuritic chest pain, and pericardial rub. Also, PPS diagnosis was also established in patients with pericardial and/or pleural effusion after cardiac surgery with non-confirmed etiology that responded well to NSAID, corticosteroid or colchicine therapy. All echocardiographic analyses were performed on a Vivid 4 (General Electric, USA). CRP was determined in plasma using standard biochemical method and expressed in mg/L. In case of pleural or pericardial drainage, lactate dehydrogenase, total protein and albumin levels were identified in drained fluid and plasma using standard biochemical methods and analyzed using Light criteria ${ }^{5}$.

\section{Subanalysis of patients referred for aortic valve or aorta surgery}

Demographic and clinical characteristics of $58 \mathrm{pa}^{-}$ tients referred for aortic valve or aorta surgery were analyzed in regard to PPS occurrence between 1 and 6 weeks after the procedure.

\section{Statistical analysis}

Continuous variables were expressed as median and range, and categorical variables as percentages. The $\chi^{2}$-test was used to determine difference in proportions between the groups. Multivariable Cox regression was used to analyze the impact of the main demographic and clinical characteristics on the incidence of PPS in patients undergoing surgery of the aorta and aortic 
valve. Statistical significance was set at $\mathrm{p}<0.05$. Statistical analysis was performed using SPSS 12.0 software (IBM, USA).

\section{Results}

Out of a total of 461 patients referred for cardiac surgery between 2009 and 2015, moderate or severe form of PPS that required medical attention was diagnosed in $47(10.2 \%)$ patients. The average time from the surgery to the onset of the disease was 14 days. Features of patients with the criteria for PPS diagnosis are shown in Table 1.

Table 1. Clinical characteristics of 47 patients with postpericardiotomy syndrome treated between March 2009 and October 2015

\begin{tabular}{|l|l|}
\hline Clinical characteristic & Number (\%) \\
\hline Age (years), median (range) & $61(65)$ \\
Gender, male & $35(74)$ \\
Time to diagnosis (days), & $14(33)$ \\
median (range) & $19(40)$ \\
Fever & $53(114)$ \\
C-reactive protein (mg/L), & $10(21)$ \\
median (range) & $9(19)$ \\
Diabetes mellitus type 2 & $40(85)$ \\
Chronic renal insufficiency & $35(74)$ \\
Pleural effusion & $15(32)$ \\
Pericardial effusion & $1(2)$ \\
Pleural percutaneous drainage & \\
Pericardial percutaneous drainage &
\end{tabular}

Differences in the frequency of PPS depending on the type of cardiac procedure are shown in Figure 1. PPS incidence after aortic valve and/or aorta surgery was $26 \%$, whereas its incidence after isolated aortocoronary bypass surgery or mitral valve surgery was significantly lower (Fig. 1).

All patients achieved remission after conservative medical therapy, most commonly with corticosteroids in $36(77 \%)$ patients, and with NSAIDs or colchicine in $11(23 \%)$ patients. There were two documented cases of recurrence of the disease after initial corticosteroid therapy, which were successfully treated with colchicine. In 15 (32\%) patients, pleural drainage was performed due to large pleural effusion, whereas only one $(2 \%)$ patient needed pericardiocentesis.

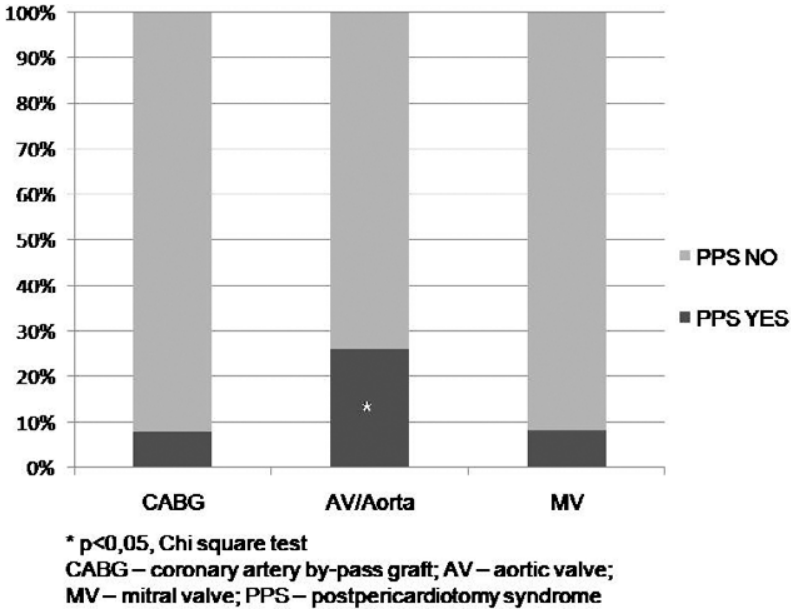

Fig. 1. Significantly higher proportion of postpericardiotomy syndrome among patients referred for surgery of the aortic valve and/or thoracic aorta compared to coronary artery bypass graft and mitral valve surgery.

Patients having undergone aortic valve/aorta surgery had the highest incidence of PPS and were selected for additional regression analysis of factors associated with confirmed PPS diagnosis. Among patients undergoing surgery of the aortic valve and/or aorta, regression analysis showed fever, elevated CRP between 5 and $100 \mathrm{mg} / \mathrm{L}$, an emergency procedure and postoperative use of antibiotics to be independent risk factors for PPS. Younger age was also prominently associated with a higher frequency of PPS; however, it did not reach statistical significance (Table 2).

\section{Discussion}

Postpericardiotomy syndrome is one of the most common cardiac surgery complications in the late postoperative period. Retrospective analysis of our data demonstrated the overall incidence of PPS of $10.2 \%$, very rare need of pericardiocentesis, and overall good prognosis after medical therapy, which corresponded to previous studies ${ }^{6}$. Corticosteroids were used in medical therapy in most patients. Previous studies describe more common administration of NSAIDs in mild forms of the disease, whereas moderate to serious forms of PPS were treated with corticosteroids, or lately more frequently with colchicine in combination with NSAIDs ${ }^{6,7}$. 
Table 2. Risk factors associated with postpericardiotomy syndrome development in 58 patients referred for aortic valve surgery and/or thoracic aorta surgery

\begin{tabular}{|c|c|c|c|c|c|}
\hline \multirow{2}{*}{\multicolumn{2}{|c|}{ Clinical characteristic }} & \multicolumn{2}{|c|}{ PPS } & \multirow[b]{2}{*}{$\mathrm{p}$ value } & \multirow[b]{2}{*}{ HR (CI) } \\
\hline & & $\begin{array}{l}\text { Yes } \\
\mathrm{n}=15\end{array}$ & $\begin{array}{l}\text { No } \\
n=43\end{array}$ & & \\
\hline \multicolumn{2}{|l|}{ Age (years), median (range) } & $65(51)$ & $69(51)$ & 0.055 & $1.136(0.978-1.264)$ \\
\hline Gender, n (\%) & \begin{tabular}{|l|} 
Male \\
Female
\end{tabular} & $\begin{array}{l}8(53) \\
7(47)\end{array}$ & $\begin{array}{l}29(67) \\
14(33)\end{array}$ & 0.328 & $0.552(0.166-1.829)$ \\
\hline NYHA $\geq 3, \mathrm{n}(\%)$ & $\begin{array}{l}\text { Yes } \\
\text { No }\end{array}$ & $\begin{array}{l}13(87) \\
2(13)\end{array}$ & $\begin{array}{l}34(79) \\
9(21)\end{array}$ & 0.506 & $1.721(0.327-9.050)$ \\
\hline LVEF <50, n (\%) & $\begin{array}{l}\text { Yes } \\
\text { No }\end{array}$ & \begin{tabular}{|l|}
$5(33)$ \\
$10(67)$
\end{tabular} & $\begin{array}{l}8(19) \\
35(81)\end{array}$ & 0.252 & $2.188(0.584-8.189$ \\
\hline $\begin{array}{l}\text { Coronary artery disease, } \\
\mathrm{n}(\%)\end{array}$ & $\begin{array}{l}\text { Yes } \\
\text { No }\end{array}$ & $\begin{array}{l}7(47) \\
8(53)\end{array}$ & $\begin{array}{l}17(39) \\
26(61)\end{array}$ & 0.630 & $1.338(0.409-4.374)$ \\
\hline $\begin{array}{l}\text { Diabetes mellitus type } 2 \text {, } \\
\mathrm{n}(\%)\end{array}$ & $\begin{array}{l}\text { Yes } \\
\text { No }\end{array}$ & \begin{tabular}{|l|}
$3(20)$ \\
$12(80)$
\end{tabular} & $\begin{array}{l}11(26) \\
32(74)\end{array}$ & 0.659 & $0.727(0.173-3.066)$ \\
\hline $\begin{array}{l}\text { Chronic renal insufficiency, } \\
\mathrm{n}(\%)\end{array}$ & $\begin{array}{l}\text { Yes } \\
\text { No }\end{array}$ & \begin{tabular}{|l|}
$3(20)$ \\
$12(80)$
\end{tabular} & $\begin{array}{l}7(17) \\
36(83)\end{array}$ & 0.746 & $1.286(0.286-5.774)$ \\
\hline COPD, n (\%) & $\begin{array}{l}\text { Yes } \\
\text { No }\end{array}$ & $\begin{array}{l}1(7) \\
14(93)\end{array}$ & $\begin{array}{l}2(5) \\
41(95)\end{array}$ & 0.767 & $1.464(0.123-17.145)$ \\
\hline Urgent procedure, $\mathrm{n}(\%)$ & $\begin{array}{l}\text { Yes } \\
\text { No }\end{array}$ & \begin{tabular}{|l|}
$2(13)$ \\
$13(87)$
\end{tabular} & $\begin{array}{l}0 \\
43(100)\end{array}$ & 0.018 & $0.867(0.711-0.957)$ \\
\hline CABG, n (\%) & $\begin{array}{l}\text { Yes } \\
\text { No }\end{array}$ & $\begin{array}{l}4(27) \\
11(73) \\
\end{array}$ & $\begin{array}{l}10(23) \\
33(77)\end{array}$ & 0.521 & $1.2(0.313-4.608)$ \\
\hline Mitral valve surgery, n (\%) & $\begin{array}{l}\text { Yes } \\
\text { No }\end{array}$ & $\begin{array}{l}0 \\
15(100)\end{array}$ & $\begin{array}{l}2(5) \\
41(95)\end{array}$ & 0.546 & $1.049(0.982-1.120)$ \\
\hline Fever postoperative, n (\%) & $\begin{array}{l}\text { Yes } \\
\text { No }\end{array}$ & $\begin{array}{l}4(27) \\
11(73)\end{array}$ & $\begin{array}{l}1(3) \\
42(97)\end{array}$ & 0.013 & $15.273(1.547-150.765)$ \\
\hline $\mathrm{CRP}>5$ mg/L, n (\%) & $\begin{array}{l}\text { Yes } \\
\text { No }\end{array}$ & $\begin{array}{l}13(87) \\
2(13)\end{array}$ & $\begin{array}{l}15(35) \\
28(65) \\
\end{array}$ & 0.001 & $12.133(2.412-61.029)$ \\
\hline $\begin{array}{l}\text { Antibiotic postoperative, } \\
\mathrm{n}(\%)\end{array}$ & $\begin{array}{l}\text { Yes } \\
\text { No }\end{array}$ & $\begin{array}{l}7(47) \\
8(53)\end{array}$ & $\begin{array}{l}5(12) \\
38(88)\end{array}$ & 0.004 & $6.650(1.677-26.357)$ \\
\hline
\end{tabular}

PPS = postpericardiotomy syndrome; NYHA = New York Heart Association functional classification; LVEF = left ventricular ejection fraction; $\mathrm{COPD}=$ chronic obstructive pulmonary disease; $\mathrm{CABG}=$ coronary artery bypass graft; $\mathrm{CRP}=\mathrm{C}$-reactive protein

In this study, a significantly higher proportion of PPS was recorded among patients undergoing surgery of the aortic valve and/or aorta, with or without CABG, compared to patients referred for other types of cardiac surgery. To date, there are no relevant studies analyzing differences in the incidence of PPS depending on the type of surgical procedure. In their prospective study, Imazio et al. report a higher incidence of PPS in females and in patients that had perioperative incision of the pleura ${ }^{8}$, whereas a Finnish group of authors found that PPS was more frequently present in patients receiving blood transfusions and in diabetic patients not treated with metformin ${ }^{6}$. However, there are no analyses of difference in the incidence of PPS among patients with coronary, mitral, or aortic surgical procedures. Our results showed a significant impact of emergency surgery and postoperative use of antibiotics, while age younger than 65 was close to statistical significance as an independent risk factor for PPS.

Since we showed a significantly higher incidence of PPS among patients having undergone surgery of the aorta and aortic valve, we assume that patients referred 
for this type of surgery may benefit from prophylactic treatment with colchicine or corticosteroids. Recently, there were several randomized trials of PPS prevention with prophylactic medical therapy, and the most studied drugs were steroids and colchicine ${ }^{9,10}$. DECS study was the largest randomized trial so far that examined the effectiveness of intraoperative application of $1 \mathrm{mg} / \mathrm{kg}$ of dexamethasone to prevent PPS, compared to placebo after cardiac surgery in more than 4000 patients. It did not justify perioperative use of colchicine ${ }^{9}$. COPPS2 study examined the feasibility of prophylactic application of colchicine compared to placebo and showed a significant reduction in the incidence of PPS in patients treated with colchicine, but no difference in the incidence of significant pleural or pericardial effusion, or atrial fibrillation. Worth noting was the very high incidence of PPS among the COPPS2 population (19.4\% of patients administered colchicine and even $29.4 \%$ of patients on placebo $)^{10}$. Consequently, there are still no clear recommendations on the justification of prophylactic treatment with corticosteroids or colchicine in particular groups of patients. However, it is important to note that the above mentioned studies did not analyze subgroups of patients depending on the type of cardiac surgery, with a particular focus on patients undergoing surgery of the aorta or aortic valve. We hypothesize that patients undergoing surgery of the aortic valve and/or thoracic aorta have a more profound immune response and are more prone to PPS. Calcified aortic stenosis has been linked with increased serum concentrations of potential inflammatory markers in previous studies ${ }^{11}$. It would be interesting to prospectively investigate the efficacy of prophylactic treatment with colchicine or corticosteroids in this patient population, with analysis of the impact of age, sex and other comorbidities on the development of PPS.

Our analysis, with important limitations of small sample, large confidence intervals and retrospective design, showed the incidence of PPS to be similar to earlier studies with a relatively benign course of the disease. This study has also generated the hypothesis that younger patients referred for aortic valve and/or thoracic aorta surgery without associated comorbidities have a higher risk of developing PPS and are an interesting group for future analysis of PPS prevention with colchicine or corticosteroids.

\section{References}

1. Miller RH, Horneffer PJ, Gardner TJ, Rykiel MF, Pearson TA. The epidemiology of the postpericardiotomy syndrome: a common complication of cardiac surgery. Am Heart J. 1988;116: 1323-9.

2. Bartels C, Honig R, Burger G, Diehl V, de Vivie R. The significance of anticardiolipin antibodies and anti-heart muscle antibodies for the diagnosis of postpericardiotomy syndrome. Eur Heart J. 1994;15:1494-9.

3. Imazio M, Trinchero R, Brucato A, Ferrazzi P, Rovere ME, Gandino A, et al.; COPPS Investigators. Colchicine for the Prevention of the Postpericardiotomy Syndrome (COPPS): a multicentre, randomized, double-blind, placebo-controlled trial. Eur Heart J. 2010;31:2749-54.

4. Imazio M, Hoit BD. Post-cardiac injury syndromes: an emerging cause of pericardial diseases. Int J Cardiol. 2013;168: 648-52.

5. Light RW. The Light criteria: the beginning and why they are useful 40 years later. Clin Chest Med. 2013;34:21-6. doi: 10.1016/j.ccm.2012.11.006.

6. Lehto J, Gunn J, Karjalainen P, Airaksinen J, Kiviniemi T. Incidence and risk factors of postpericardiotomy syndrome requiring medical attention: The Finland Postpericardiotomy Syndrome study. J Thorac Cardiovasc Surg. 2015;15:51-3.

7. Horneffer PJ, Miller RH, Pearson TA, Rykiel MF, Reitz BA, Gardner TJ. The effective treatment of postpericardiotomy syndrome after cardiac operations: a randomized placebo controlled trial. J Thorac Cardiovasc Surg. 1990;100(2):292-6.

8. Imazio M, Brucato A, Rovere ME, Gandino A, Cemin R, Ferrua $\mathrm{S}$, et al. Contemporary features, risk factors, and prognosis of the postpericardiotomy syndrome. Am J Cardiol. 2011;108: 1183-7.

9. Bunge JJ, van Osch D, Dieleman JM, Jacob KA, Kluin J, van Dijk D, Nathoe HM; Dexamethasone for Cardiac Surgery (DECS) Study Group. Dexamethasone for the prevention of postpericardiotomy syndrome: a DExamethasone for Cardiac Surgery substudy. Am Heart J. 2014;168:126-31.

doi: 10.1016/j.ahj.2014.03.017.

10. Imazio M, Brucato A, Ferrazzi P, Pullara A, Adler Y, Barosi A, et al.; COPPS-2 Investigators. Colchicine for prevention of postpericardiotomy syndrome and postoperative atrial fibrillation: the COPPS-2 randomized clinical trial. JAMA. 2014; 312:1016-23. doi: 10.1001/jama.2014.11026.

11. Makarović S, Makarović Z, Bilić-Ćurčić I, Milas-Ahić J, Mihaljević I, Franceschi M, et al. Serum osteoprotegerin in patients with calcified aortic valve stenosis in relation to heart failure. Acta Clin Croat. 2017;56:733-41. doi: 10.20471/ acc.2017.56.04.22. 
Sažetak

\title{
POSTPERIKARDIOTOMIJSKI SINDROM - UČESTALOST, DIJAGNOSTIČKI KRITERIJI I LIJEČENJE: ISKUSTVA SURADNJE DVAJU CENTARA
}

\author{
K. Gabaldo, Ž. Sutlić, D. Mišković, M. Knežević Praveček, Đ. Prvulović, B. Vujeva, \\ K. Cvitkušić Lukenda i I. Hadžibegović
}

Postperikardiotomijski sindrom (PPS) je pogoršanje ili novo stvaranje perikardijalnog i/ili pleuralnog izljeva uglavnom 1 do 6 tjedana nakon kardiokirurške operacije, i to kao rezultat autoimune upalne reakcije unutar pleuralnog i perikardijalnog prostora. Njegova učestalost varira među različitim studijama i registrima (između 2\% i 30\%), kao i prema vrsti kirurškog zahvata koji je proveden. Proveli smo retrospektivnu analizu učestalosti PPS-a i dijagnostičkih i terapijskih strategija u bolesnika upućenih na kardiokirurgiju radi revaskularizacije, valvularne i/ili kirurgije torakalne aorte. Retrospektivno smo analizirali 461 bolesnika upućenog na hitan ili elektivni kardiokirurški zahvat između 2009. i 2015. godine. Dijagnoza PPS-a utvrđena je pomoću dobro definiranih kliničkih kriterija. Demografske i kliničke karakteristike korištene su u regresijskoj subanalizi kod bolesnika koji su bili podvrgnuti operaciji aortnog zaliska i/ili uzlazne aorte. U roku od 6 tjedana nakon zahvata 47 (10,2\%) bolesnika razvilo je PPS. Srednje vrijeme od postupka do dijagnoze PPS bilo je 14 dana. Učestalost PPS-a bila je $26 \%$ nakon operacije aortnog zaliska i/ili torakalne aorte te 7,9\% i 8,3\% nakon izoliranog koronarnog premoštenja odnosno operacije mitralnog zaliska. Među bolesnicima koji su bili podvrgnuti kirurškom zahvatu aortnog zaliska i/ili torakalne aorte regresijska analiza pokazala je značajnu povezanost povišene temperature, povišenja C-reaktivnog proteina (CRP) između 5 i $100 \mathrm{mg} / \mathrm{L}$, veće hitnosti zahvata i poslijeoperacijske uporabe antibiotika s PPS-om, dok je za mlađu dob ta povezanost bila blizu razine značajnosti. Kod gotovo svih bolesnika došlo je do povlačenja PPS-a i to uglavnom nakon terapije kortikosteroidima, pri čemu su samo 2 slučaja rekurentnog PPS-a uspješno liječena kolhicinom. Pleuralna drenaža bila je indicirana u 15 (32\%) bolesnika, dok je samo jedan bolesnik zahtijevao perikardijalnu drenažu. Zaključno, učestalost PPS-a u našoj retrospektivnoj analizi bila je slična prethodnim izvješćima. Bolesnici koji su bili podvrgnuti operacijama aortnog zaliska i/ili aorte imali su najveću učestalost PPS-a. Najrelevantniji klinički kriteriji za postavljanje dijagnoze u tih bolesnika su povišena temperatura, povišenje CRP-a između 5 i $100 \mathrm{mg} / \mathrm{L}$ te nastanak perikardijalnog i/ili pleuralnog izljeva ili njihovo pogoršanje 2 tjedna nakon kirurškog zahvata na srcu.

Ključne riječi: Kardiokirurški postupci; Poslijeoperacijske komplikacije; Perikardijalni izljev; Pleuralni izljev; Postperikardiotomijski sindrom 